\title{
Differentiation of the Oxytocum Group from Klebsiella by Deoxyribonucleic Acid-Deoxyribonucleic Acid Hybridization
}

\author{
KAMLESH JAIN, K. RADSAK, and W. MANNHEIM \\ Hygiene-Institut der Philipps-Universität, Marburg/Lahn, Federal Republic of Germany
}

\begin{abstract}
By deoxyribonucleic acid-deoxyribonucleic acid molecular hybridization, evidence was obtained that the bacteria of the Oxytocum group represent a distinct deoxyribonucleic acid homology group and are not indole-forming and gelatin-liquefying variants of Klebsiella aerogenes and Klebsiella pneumoniae (sensu lato), respectively, and not a subgroup within Klebsiella, as had been suggested previously. The establishment of a new, but presently unnamed, genus of Enterobacteriaceae, with one species, is proposed, represented by strain 497-2 of R. Hugh (ATCC 13182). Furthermore, none of a series of bacterial strains classified as Enterobacter, Hafnia, or Erwinia species was found to be related to Klebsiella or to the Oxytocum strains. The deoxyribonucleic acid reassociation values do not allow species differentiation within the true, indole-negative klebsiellae.
\end{abstract}

Attempts to give an unambiguous definition of Klebsiella by means of phenotypic criteria have led to contradictory viewpoints. Recent suggestions have been reviewed by Bascomb et al. (1) and, in part, by Stenzel et al. (26). Traditional enterobacteriological methods have failed to produce an acceptable classification of what has been named the Klebsiella-Enterobacter-Serratia division (10), perhaps because such tests cover only a small and nonrepresentative part of genome information (cf. 7). Further progress in this field, however, can be expected from investigations of taxonomic relatedness on the molecular level.

By means of deoxyribonucleic acid (DNA) reassociation, Brenner et al. (3) showed that the klebsiellae, on the one hand, and typical strains of Enterobacter aerogenes, on the other hand, represent clearly different DNA homology groups at the same rank as conventional genera. Separation of species within Klebsiella was, however, impossible, but the systematic position of the so-called Oxytocum strains was not considered. Bacillus oxytocus perniciosus (13) has so far been classified as: (i) a distinct taxonomic unit within the family. Enterobacteriaceae (21), (ii) a Klebsiella species $(20,26)$, and (iii) a subspecies of Klebsiella pneumoniae (11) or Klebsiella aerogenes (1). The present investigation was undertaken to examine the relationship between Oxytocum strains and members of the Klebsiella group by means of DNA-DNA hybridization

\section{MATERIALS AND METHODS}

Microorganisms. The bacterial strains used are listed in Table 1. They were kept in a freeze-dried state under vacuum and for short periods (weeks) on tryptic soy agar (Difco Laboratories) at $4 \mathrm{C}$.

Media and cultivation. Fernbach flasks containing $200 \mathrm{ml}$ of medium were inoculated with $1 \%(\mathrm{vol} / \mathrm{vol})$ of late exponential cultures and incubated aerobically (G-25 gyrorotatory shaker, New Brunswick Scientific Co, $200 \mathrm{rpm}$ ) at $30 \mathrm{C}$. Unlabeled DNA was prepared from bacteria grown in a complex medium containing $2.0 \mathrm{~g}$ of proteose peptone no. 3 (Difco), $0.5 \%(\mathrm{wt} / \mathrm{vol}) \mathrm{NaCl}$, and tris(hydroxymethyl)aminomethane q.s. (pH 7.4), sterilized for $15 \mathrm{~min}$ at $121 \mathrm{C}$, and $0.2 \%(\mathrm{wt} / \mathrm{vol}) \mathrm{D}(+)$-glucose, sterilized by filtration. Labeled DNA was recovered from bacteria grown in ammonium glucose medium $[0.5 \mathrm{~g}$ of $\mathrm{NaCl}, 0.02 \mathrm{~g}$ of $\mathrm{MgSO}_{4} \cdot 7 \mathrm{H}_{2} \mathrm{O}, 0.1 \mathrm{~g}$ of $\left(\mathrm{NH}_{4}\right) \mathrm{H}_{2} \mathrm{PO}_{4}$, and $0.1 \%$ (wt/vol) $\mathrm{K}_{2} \mathrm{HPO}_{4}$, sterilized by heat; $0.05 \mathrm{M} \mathrm{D}(+$ )glucose and $0.01 \mathrm{M} \mathrm{NaHCO}_{3}$, sterilized by filtration) which had been supplemented with $1 \mu \mathrm{Ci}$ of [methyl${ }^{3} \mathrm{H}$ ] thymidine per $\mathrm{ml}$ before inoculation (Amersham Buchler Ltd., specific activity ca. $20 \mathrm{Ci} / \mathrm{mmol}$ ). The cultures were harvested in the late exponential phase at $10,000 \times g(4 \mathrm{C})$, washed twice with 1 to $1.5 \times$ SSC $(0.15 \mathrm{M} \mathrm{NaCl}$ plus $0.15 \mathrm{M}$ sodium citrate) and stored at $-25 \mathrm{C}$.

Preparation, purification, and estimation of bacterial DNA base composition. DNA was extracted from washed bacterial sediments according to a modification (18) of the method described by Marmur 
TABLE 1. Identity and source of bacterial strains used

\begin{tabular}{|c|c|c|}
\hline Organism & Strain & Source \\
\hline Klebsiella oxy toca & $497-2$ & ATCC 13182 \\
\hline K. oxytoca & $533-1$ & ATCC 13183 \\
\hline K. oxytoca & $25871 / 68$ & HIM 382-3 \\
\hline K. oxytoca & E $172 / 68$ & Stenzel \\
\hline K. pneumoniae & CDC $298 / 53$ & NCTC 9633 \\
\hline K. pneumoniae & E $121 / 68$ & Stenzel \\
\hline K. pneumoniae & V $1942 / 69$ & Stenzel \\
\hline K. pneumoniae & $35584 / 69$ & HIM 341-5 \\
\hline$K$. aerogenes & E 672 & Lapage \\
\hline$K$. aerogenes & E 674 & Lapage \\
\hline $\begin{array}{l}\text { K. edwardsii } \\
\text { subsp. edwardsii } \\
\text { K. edwardsii }\end{array}$ & F1 & NCTC 5054 \\
\hline $\begin{array}{l}\text { subsp. atlantae } \\
\text { Klebsiella } \mathrm{sp.}\end{array}$ & CDC $4610 / 53$ & NCTC 9496 \\
\hline $\begin{array}{l}\text { (unnamed) } \\
\text { Klebsiello sp. }\end{array}$ & E $45 / 67$ & Lapage \\
\hline (unnamed) & E 46/67 & Lapage \\
\hline K. ozaenae & McLurry & NCTC 9657 \\
\hline $\begin{array}{l}K . \text { ozaenae } \\
K . \text { rhinoscler }\end{array}$ & AMC 35-E6 & NCTC 5051 \\
\hline $\begin{array}{l}\text { matis } \\
K . \text { rhinosclero- }\end{array}$ & R 70 & NCTC 5046 \\
\hline $\begin{array}{l}\text { matis } \\
\text { K. rhinosclero- }\end{array}$ & 5 Sumatra & NCTC 1936 \\
\hline $\begin{array}{l}\text { matis } \\
\text { Enterobacter }\end{array}$ & Muggia & ATCC 9436 \\
\hline aerogenes & $819 / 56$ & NCTC 10006 \\
\hline E. cloacae & $279 / 56$ & NCTC 10005 \\
\hline E. carotovorus $b$ & 904 & CCM 1008 \\
\hline E. agglomerans ${ }^{c}$ & CDC $1461 / 67$ & NCTC 9381 \\
\hline Hafnia alvei & Cadaveris & NCTC 6578 \\
\hline Erwinia amylovora & S59/5 & CCM 114 \\
\hline Escherichia coli & U 5/41 & NCTC 9001 \\
\hline E. coli & $\mathrm{K}-12, \mathrm{~W}-1485$ & ATCC 12435 \\
\hline E. coli & Luria B & Martin \\
\hline
\end{tabular}

a ATCC, American Type Culture Collection; CCM, Czechoslovak Collection of Microorganisms; HIM, Culture Collection of Institute of Hygiene, Faculty of Medicine, Philipps University, Marburg/Lahn, West Germany; Lapage, S.P. Lapage, London; NCTC, National Collection of Type Cultures, London; Martin, H. H. Martin, Darmstadt; Stenzel, W. Stenzel, Moers.

$b$ cf. Martinec and Kocur (24).

${ }^{c}$ cf. Ewing and Fife (12).

(23). DNA was treated further with $0.01 \%$ (wt/vol) acid-washed Norite (Serva Feinbiochemica GmbH. Co., Heidelberg, Germany) to remove traces of polysaccharide and protein (5). Ultraviolet spectra of the final DNA preparation dissolved in $0.1 \times$ SSC were recorded (i) to detect residual protein contamination, (ii) to determine DNA concentration, and (iii) to estimate base composition by the method of Ulitzur (27). Specific activities of different radioactive DNA preparations were between 3,000 and 6,000 counts per min per $\mu \mathrm{g}$ of DNA.
DNA-DNA hybridization. DNA-DNA hybridization was carried out by using the membrane filter method of Denhardt (9) with the following modifications. Cellulose membrane filters (pore width, $0.45 \mu \mathrm{m}$; diameter, 25 mm; no. SM 11306 , Sartorius, Göttingen, Germany) were loaded with $5 \mu \mathrm{g}$ of nonradioactive heat-denatured DNA, dried for $4 \mathrm{~h}$ at $80 \mathrm{C}$, and incubated with a 10-fold excess (near saturation of homologous DNAs) of sonically denatured radioactive DNA, in $1.2 \mathrm{ml}$ of buffer solution containing $5.2 \times$ SSC and $48 \%$ (wt/vol) formamide (24), for $48 \mathrm{~h}$ at 46 C. Thus, reassociation took place under restrictive conditions corresponding to about 8 to $10 \mathrm{C}$ below the melting temperature of Klebsiella DNA. After incubation, filter disks were washed thoroughly with 2 $x$ SSC, dried, and counted in a toluene-based scintillation fluid in a Nuclear-Chicago liquid scintillation counter. Counting efficiency was approximately $38 \%$. On the basis of specific radioactivities, binding values for the homologous reactions were about $2 \%$ of the input radioactive DNA.

\section{RESULTS}

Klebsiella oxytoca strain 497-2 of Hugh (ATCC 13182), Klebsiella pneumoniae (sensu strictiori, cf. Cowan et al. [6]) strain CDC 298/53 (NCTC 9633), and Klebsiella aerogenes strain E 672 of Lapage (1) were selected as donors of radioactively labeled DNA. Binding values between these DNAs and those of the organisms listed in Table 1 , i.e, representatives of a variety of taxa considered to belong to the Klebsiella or Enterobacter, were determined. In addition, three representative Escherichia strains were included. As indicated by ultraviolet absorbance ratios (245/270 $\mathrm{nm}$; approximately 0.9 for all DNAs used), the DNA base composition of all samples appeared to be in the same range, in agreement with data published so far (cf. 8, 17). Hybridization conditions were, therefore, applied uniformly to all tests. Binding values are summarized in Table 2.

Reassociation of radioactive Oxytocum DNA. Labeled DNA of strain 497-2 was bound by the DNAs of two other Oxytocum strains to a high extent and by the DNA of a third Oxytocum strain to an intermediate extent. In contrast, reactions with DNAs of the indolenegative klebsiellae and the other organisms tested yielded moderate to low binding values.

Reassociation of radioactive DNAs of $K$. pneumoniae and $K$. aerogenes. Labeled DNAs of strains CDC 298/53 and E 672 exhibited comparable affinities, yielding intermediate to high reassociation values with DNAs of indole- 
TABLE 2. Reaction of /methyl- ${ }^{3} \mathrm{H}$ ]-labeled DNA

fragments from representative $K$. oxytoca, $K$. pneumoniae, and $K$, aerogenes strains with DNA from various Enterobacteriaceae

\begin{tabular}{|c|c|c|c|}
\hline \multirow{2}{*}{$\begin{array}{l}\text { Source of immobil- } \\
\text { ized, unlabeled DNA }\end{array}$} & \multicolumn{3}{|c|}{$\begin{array}{l}\text { Labeled DNA, relative } \\
\text { binding } g^{a}(\%)\end{array}$} \\
\hline & $\begin{array}{l}\text { K. oxy- } \\
\text { toca } \\
497-2\end{array}$ & $\begin{array}{l}K . \text { pneu- } \\
\text { moniae } \\
C D C \\
298 / 53\end{array}$ & $\begin{array}{l}\text { K. aero- } \\
\text { genes } \\
\text { E } 672\end{array}$ \\
\hline $\begin{array}{l}\text { K. oxytoca: } \\
\quad 497-2 \\
533-1 \\
25871 / 68 \\
\text { E } 172 / 68\end{array}$ & $\begin{array}{r}100 \\
90 \\
34 \\
70\end{array}$ & $\begin{array}{l}22 \\
19 \\
18 \\
13\end{array}$ & $\begin{array}{l}15 \\
\text { NT }^{b} \\
\text { NT } \\
\text { NT }\end{array}$ \\
\hline $\begin{array}{l}\text { K. pneumoniae: } \\
\text { CDC } 298 / 53 \\
\text { E } 121 / 68 \\
\text { V } 1942 / 69 \\
35884 / 69\end{array}$ & $\begin{array}{r}22 \\
13 \\
7 \\
8\end{array}$ & $\begin{array}{r}100 \\
72 \\
47 \\
45\end{array}$ & $\begin{array}{l}86 \\
52 \\
\text { NT } \\
\text { NT }\end{array}$ \\
\hline $\begin{array}{l}\text { K. aerogenes: } \\
\text { E } 672 \\
\text { E } 674\end{array}$ & $\begin{array}{r}12 \\
8\end{array}$ & $\begin{array}{l}66 \\
48\end{array}$ & $\begin{array}{r}100 \\
72\end{array}$ \\
\hline $\begin{array}{l}\text { K. edwardsii: } \\
\text { F } 1 \\
\text { CDC. } 4610 / 53\end{array}$ & $\begin{array}{r}5 \\
11\end{array}$ & $\begin{array}{l}56 \\
58\end{array}$ & $\begin{array}{l}77 \\
73\end{array}$ \\
\hline $\begin{array}{l}\text { Klebsiella sp.: } \\
\text { E 45/67 } \\
\text { E 46/67 }\end{array}$ & $\begin{array}{r}12 \\
8\end{array}$ & $\begin{array}{l}61 \\
58\end{array}$ & $\begin{array}{r}85 \\
\text { NT }\end{array}$ \\
\hline $\begin{array}{l}\text { K. ozaenae: } \\
\text { McLurry } \\
\text { AMC 35-E6 }\end{array}$ & $\begin{array}{l}15 \\
10\end{array}$ & $\begin{array}{l}48 \\
83\end{array}$ & $\begin{array}{l}69 \\
71\end{array}$ \\
\hline $\begin{array}{l}\text { K. rhinoscleromatis: } \\
\text { R } 70 \\
5 \text { Sumatra } \\
\text { Muggia }\end{array}$ & $\begin{array}{l}10 \\
10 \\
23\end{array}$ & $\begin{array}{l}74 \\
67 \\
55\end{array}$ & $\begin{array}{r}89 \\
78 \\
\text { NT }\end{array}$ \\
\hline E. aerogenes $819 / 56$ & 12 & 17 & 22 \\
\hline E. cloacae $279 / 56$ & 11 & 11 & 16 \\
\hline E. carotovorus 904 & 3 & 5 & NT \\
\hline $\begin{array}{l}\text { E. agglomerans } \\
\text { CDC } 1461 / 67\end{array}$ & 5 & 7 & NT \\
\hline H. alvei Cadaveris & 2 & 4 & NT \\
\hline E. amylovora $\mathrm{S} 59 / 5$ & 4 & 5 & NT \\
\hline $\begin{array}{l}\text { E. coli } \\
\text { U 5/41 } \\
\text { K-12, W-1485 } \\
\text { Luria B }\end{array}$ & $\begin{array}{l}7 \\
6 \\
6\end{array}$ & $\begin{array}{r}\text { NT } \\
10 \\
8\end{array}$ & $\begin{array}{r}\text { NT } \\
11 \\
\text { NT }\end{array}$ \\
\hline
\end{tabular}

${ }^{a}$ Specific radioactivities of different DNA preparations were between 3,000 and 6,000 counts per min per $\mu \mathrm{g}$ of DNA. Mean values of at least three experiments are listed.

${ }^{b}$ NT, Not tested. negative klebsiellae, moderate binding values with Oxytocum, Enterobacter aerogenes, Enterobacter cloacae, and Escherichia DNAs, and low binding values with Enterobacter carotovorus, Enterobacter agglomerans, Hafnia alvei, and Erwinia amylovora DNAs.

\section{DISCUSSION}

Since the results given in Table 2 represent reassociation values under rather restrictive conditions, they cannot be compared directly with those obtained by more permissive procedures. The reactions observed under the conditions described have to be considered, however, as highly indicative of the degree of homology between the participants of the reaction. Heat stability of the heteroduplexes as an exact criterion of the degree of homology was not examined.

The results presented might be invalidated by differences in length of chromosomal DNA molecules, which cannot be ruled out according to data reported (cf. 8), but which were considered of minor importance for the present study. However, the majority of both recently isolated and old collection cultures of Enterobacteriaceae may contain one or more species of plasmid DNA (4). This was confirmed for the organisms that were investigated by detection of multiple drug resistance (Table 3) and/or by demonstration of circular extrachromosomal DNA by ethidium bromidecesium chloride density centrifugation (unpublished data). In general, the amount of plasmid DNA is considered to be relatively small compared to the amount of chromosomal DNA $(15,25)$. However, different kinetics of DNA synthesis during early growth of bacterial cultures may yield labeled extrachromosomal DNA of relatively high specific activity. Therefore, interference of reassociation of nonchromosomal DNA cannot be ruled out for the results reported here.

Although an entirely different set of bacterial strains was investigated, the results presented exhibit the same tendency as those of Brenner et al. (3), which show a clear distinction between Klebsiella and Enterobacter species. including $E$. aerogenes, but no significant differences between species within the indoleand gelatin-negative klebsiellae. In particular, the binding values observed do not indicate whether $K$. aerogenes. $K$. pneumoniae (sensu strictiori), $K$. edwardsii, and the "unnamed" subgroup described by Bascomb et al. (1) are different species or not. This holds true also for the recognized species $K$. ozaenae and $K$. rhinoscleromatis. 
TABLE 3. Drug resistance and circular DNA

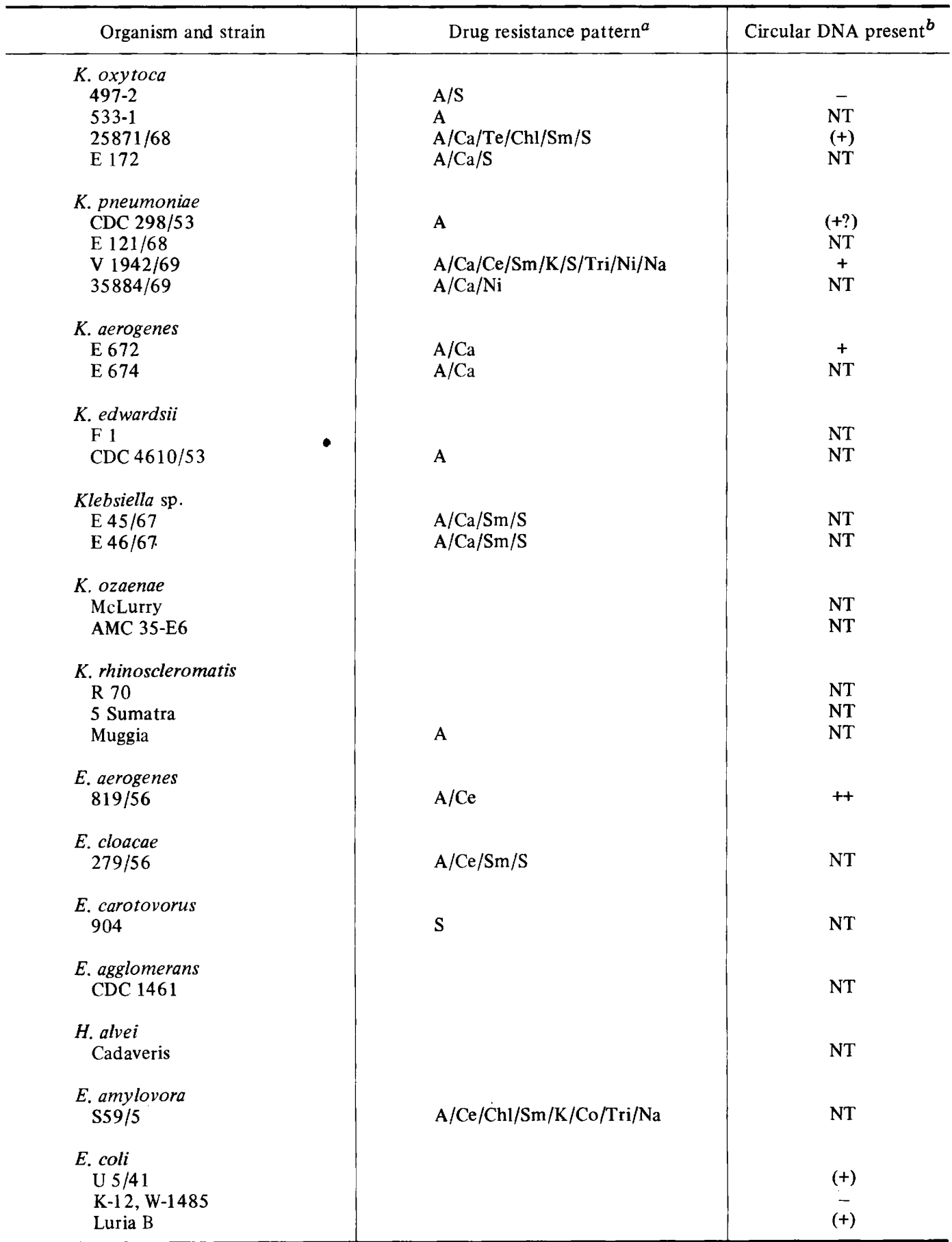

${ }^{a}$ Multodisc (Oxoid) diffusion test on Mueller-Hinton agar; A, ampicillin (10 $\left.\mu \mathrm{g}\right)$; Ce, Cephalothin (15 $\left.\mu \mathrm{g}\right)$; Te, tetracycline $(10 \mu \mathrm{g})$; Chl, chloramphenicol $(10 \mu \mathrm{g}) ; \mathrm{S}$, sulfafurazole $(100 \mu \mathrm{g})$; Tri, trimethoprim $(1.25 \mu \mathrm{g})$; Ca, carbenicillin $(100 \mu \mathrm{g}) ; \mathrm{Sm}$, streptomy cin $(2 \mu \mathrm{g}) ; \mathrm{K}$, kanamy cin $(5 \mu \mathrm{g}) ; \mathrm{Co}$, colistin $(50 \mu \mathrm{g}) ; \mathrm{Ni}$, nitrofurantoin $(50$ $\mu \mathrm{g})$; Na, nalidixic acid $(30 \mu \mathrm{g})$.

Isolated by isopycnic centrifugation in cesium chloride-ethidium bromide by the method of Goebel and Schrempf (16). NT, Not tested. 
Furthermore, the data of Table 2 suggest that the variety of phenotypically related organisms that have been classified in Enterobacter may contain several other DNA homology groups of Enterobacteriaceae $(2,14)$. As for Erwinia amylovora, Jediss (19) suggested that this taxon does not belong to Enterobacteriaceae.

In spite of the small number of Oxytocum strains (two American strains and two isolated in Germany) investigated, the results presented clearly indicate that the Oxytocum group represents a distinct DNA homology group that should be classified separately from Klebsiella. This finding confirms Lautrop's view (21) that the Oxytocum strains form a distinct generic group of organisms. The phylogenetic relatedness of the Oxytocum group to Klebsiella may be approximately similar to that of Enterobacter aerogenes, and the relatedness to Escherichia may be even closer than to Klebsiella. Consequently, on the basis of Lautrop's proposal and the data presented, a new genus with one species should be established that will conform widely to the phenotype of Klebsiella oxytoca as described by Kaluzewski (20) and by Stenzel et al. (26). Strain 497-2 of R. Hugh (ATCC 13182) is a typical representative of this taxon. However, the questions of the type strain and name of the new taxon have to await further investigations.

The proposal of another new genus of Enterobacteriaceae might contribute to further confusion for the bacteriologist, since $O x y$ tocum organisms look like true klebsiellae in nearly every respect except indole reaction. However, the evaluation of clinical, epidemiological, and ecological properties of the $O x y$ tocum group will depend on their proper distinction from Klebsiella. For the purposes of food and water control, the new taxon may be useful, since production of both gas and indole at $45 \mathrm{C}$ will be restricted to one genus of Enterobacteriaceae, Escherichia, whereas klebsiellae retain only the ability to form gas in Eijkman's test, and the new taxon retains only the ability to produce indole (cf. 26).

\section{ACKNOWLEDGMENTS}

We are indebted to S. P. Lapage for helpful criticism and to W. Stieler for excellent technical assistance.

\section{REPRINT REQUESTS}

Address reprint requests to: Professor W. Mannheim, D-355, Pilgrimstein 2, Marburg, Germany.

\section{LITERATURE CITED}

1. Bascomb, S., S. P. Lapage, W. R. Willcox, and M. A. Curtis. 1971. Numerical classification of the tribe Klebsielleae. J. Gen. Microbiol. 66:279-295.

2. Brenner, D. J., G. R. Fanning, and A. G. Steigerwalt. 1972. Deoxyribonucleic acid relatedness among species of Erwinia and between Erwinia species and other enterobacteria. J. Bacteriol. 110:12-17.

3. Brenner, D. J., A. G. Steigerwalt, and G. R. Fanning. 1972. Differentiation of Enterobacter aerogenes from Klebsiella by deoxyribonucleic acid reassociation. Int. J. Syst. Bacteriol. 22: 193-200.

4. Christiansen, C., G. Christiansen, A. Leth Bak, and A. Stenderup. 1973. Extrachromosomal deoxyribonucleic acid in different enterobacteria. J. Bacteriol, 114:367-377.

5. Church, R. B., and B. J. McCarthy. 1968. Related base sequences in the DNA of simple and complex organisms. II. The interpretation of DNA/RNA hybridization studies with mammalian nucleic acids. Biochem. Genet. 2:55-73.

6. Cowan, S. T., K. J. Steel, and C. Shaw. 1960. A classification of the Klebsiella group. J. Gen. Microbiol. 23:601-612.

7. De Ley, J. 1969. Molecular data in microbial systematics. In Systematic Biology: Proceedings of the International Conference, Ann Arbor, Michigan, 1967. Publication 1692. National Academy of Sciences, Washington, D.C.

8. De Ley, J. 1969. Compositional nucleotide distribution and the theoretical prediction of homology in bacterial DNA. J. Theoret. Biol. 22:89-116.

9. Denhardt, D. T. 1966. A membrane-filter technique for the detection of complementary DNA. Biochem. Biophys. Res. Commun. 23:641-646.

10. Edwards, P. R., and W. H. Ewing. 1962. Identification of Enterobacteriaceae. Burgess Publishing Co., Minneapolis.

11. Ewing, W. H. 1963. An outline of nomenclature for the family Enterobacteriaceae. Int. Bull. Bacteriol. Nomencl. 13:95-110.

12. Ewing, W. H., and M. A. Fife. 1972. Enterobacter agglomerans (Beijerinck) comb. nov. (the herbicola-lathyri bacteria). Int. J. Syst. Bacteriol. 22:4-11.

13. Fluegge, C. 1886. Die Mikroorganismen, 1 st ed. Vogel, Leipzig.

14. Gardner, J. M., and C. J. Kado. 1973. Comparative base sequence homologies of the deoxyribonucleic acids of Erwinia species and other Enterobacteriaceae. Int. J. Syst. Bacteriol. 22:201-209.

15. Goebel, W., and H. Schrempf. 1971. Isolation and characterization of supercoiled circular deoxyribonucleic acid from beta-hemolytic strains of Escherichia coli. J. Bacteriol. 106:311-317. 
16. Goebel, W., and H. Schrempf. 1972. Isolation of minicircular deoxyribonucleic acids from wild strains of Escherichia coli and their relationship to other bacterial plasmids. J. Bacteriol. 11:696-704.

17. Hill, L. R. 1966. An index to deoxyribonucleic acid base compositions of bacterial species. J. Gen. Microbiol. 44:419-437.

18. Jain, K. 1971. Genaktivierung während der primären Derminationsphase des Grillenkeimes. Untersuchungen mittels der RNS-DNS Hybridisierungstechnik. Inaug. Dis., Heidelberg.

19. Jediss, R. 1973. Cytochrome und respiratorische Chinone der Enterobacteriaceae. Inaug. Dis., Marburg.

20. Kaluzewski, S. 1967. Taksonomiczna pozycja indolododatnich szczepów Klebsiella. Med. Dosw. Microbiol. 19:327-335.

21. Lautrop, H. 1956. Gelatin-liquefying Klebsiella strains (Bacterium oxytocum (Flügge)). Acta Pathol. Microbiol. Scand. 39:375-384.

22. McConaughy, B. L., C. D. Laird, and B. J.
McCarthy. 1969. Nucleic acid reassociation in formamide. Biochemistry 8:3289-3295.

23. Marmur, J. 1961. A procedure for the isolation of deoxyribonucleic acid from microorganisms. J. Mol. Biol. 3:208-218.

24. Martinec, T., and M. Kocur. 1968. On the taxonomic position of Erwinia carotovora. Folia Fac. Sci. Natur. Univ. Purkynianae Brunensis 9:63-67.

25. Rownd, R., R. Nakaya, and A. Nakamura. 1966. Molecular nature of the drug-resistance factors of the Enterobacteriaceae. J. Mol. Biol. 17:376-393.

26. Stenzel, W., H. Bürger, and W. Mannheim. 1972. Zur Systematik und Differentialdiagnostik der Klebsiella-Gruppe mit besonderer Berücksichtigung der sog. Oxytocum-Typen. Zentralbl. Bakteriol. Parasitenk. Infektionskr. Hyg. Abt. I Orig. 219:193-203.

27. Ulitzur, S. 1972. Rapid determination of DNA base composition by ultraviolet spectroscopy. Biochim. Biophys. Acta 272:1-11. 